\title{
LAATU ON MYÖS LUOTTAMUKSEN RAKENTAMISTA
}

\author{
Päivi Tuomola-Karp väitteli 11. maaliskuuta 2005 kansanopistojen \\ laatukäsityksestä. Käsitykset laadusta olivat kertomuksia hyvästä \\ kansanopistotyöstä ja sen puutteista, mutta ne olivat myös oman työn ja \\ opiston legitimointia. Laadun parantamisen katsottiin edellyttävän toi- \\ saalta vakiintuneiden toimintatapojen kehittämistä, toisaalta jyrkkää \\ toimintaorientaation muutosta. Laatu ei osoittautunut monoliittiseksi \\ käsitteeksi ja ilmiöksi: se, mikä yhdestä näkökulmasta tarkasteltuna on \\ myönteinen haaste, on toisesta näkökulmasta uhka.
}

\section{PÄIVI TUOMOLA-KARP}

$\mathrm{T}$ biminnan ja hyödykkeiden laadusta on tullut yritysten ja organisaatioiden yksi keskeinen kilpailukeino ja erottautumisväline markkinoilla. Laatu liittyy vaihdantaan ja siten markkinaohjaukseen. Lillrank (1999) määrittelee laadun vaihdannassa näkyväksi ominaisuudeksi, joka vaikuttaa asiakkaan arviointeihin ja päätöksiin. Laatuajattelulla ymmärretään organisaation kokonaisvaltaista johtamista ja kehittämistä. Sitä voidaan pitää myös erityisenä organisaatiokulttuurin müotona. Pyrkimys hyvään laatuun ei tietenkään sinänsä ole mikään uusi asia. Laadun käsitteellistäminen ja operationalisointi teollisuustuotannon tarpeisiin ja sittemmin näiden laatuajatusten toteuttaminen myös muilla yhteiskunnan aloilla on kuitenkin viime vuosikymmenien ilmiö.

Useissa OECD-maissa markkinatyyppisiä mekanismeja, kuten tulosohjaus, toimilupakäytäntö, tilaaja-tuottajamalli, koulutusseteli, on tuotu koulutuksen hallintoon ja ohjaukseen. Pyrkimyksenä on ollut siirtyä opetus- ja instituutiokeskeisyydestä asiakas- ja heidän valintojensa ohjaamaan oppimismarkkinakeskeisyyteen. Kilpailun resursseista uskotaan edistävän tehokkuutta ja laadunarvioinnin takaavan toiminnan laadun. (Ks. Varmola 2002; Virtanen 2002.) Kansanopistojen siirtyminen viime vuosikymmenellä normiohjauksesta informaatio-ohjaukseen on tuonut laatutyön myös kansanopistoihin. Kansanopistojen toimintarationaliteetin muutos, siirtyminen menoperusteisesta valtionapujärjestelmästä suoriteperusteiseen laskennalliseen valtionosuuteen, on siirtänyt päätökset resurssien käytöstä oppilaitostasolle.

Uudistukset ja uudet ajattelutavat muuttavat käytäntöjä, mutta uudet käytännöt muuttavat myös ajattelutapoja. Hannu Simola (2001) toteaakin, että uudistukset kyllä muuttavat koulua, mutta harvoin siihen suuntaan kuin on aiottu”. Siksi Simolan mukaan olisi pikemminkin tutkittava, "miten koulut muuttavat uudistuksia kuin sitä, miten uudistukset muuttavat kouluja”. Tutkimuksessani Laatu luottamuksen rakentamisena lähdin selvittämään, mitä kansanopistoväki laadulla ymmärtää. ${ }^{1}$

Tutkimuksen tulos on, että kansanopistoväen laatukäsitys ja kansanopistotoiminnan laatu saavat viisi ulottuvuutta, jotka ovat organisaation suorituskyvyn parantaminen, muutosvalmius, organisaation läpinäkyvyys, markkinalähtöisyys sekä jatkuvuus ja dynaaminen itseymmärrys. Laatua määritellessään haastateltavat kertoivat omista odotuksistaan ja toiveistaan sekä odotuksista, joita he kokivat itselleen asetetun ja joita he itseasiassa haastatteluissa itselleen ja talon toiminnalle asettivat. Käsitykset laadusta olivat kertomuksia hyvästä kansanopistotyöstä ja sen puutteista, mutta ne olivat myös oman työn ja opiston legitimointia. Laadun parantamisen katsottiin edellyttävän toisaalta vakiintuneiden toimintatapojen kehittämistä toisaalta jyrkkää toimintaorientaation muutosta. Laatu ei osoittautunut monoliittiseksi käsitteeksi ja ilmiöksi: se, mikä yhdestä näkökulmasta tarkasteltuna on myönteinen haaste, on toisesta näkökulmasta uhka. 
Kansanopistot eroavat toisistaan tehtäväalueiltaan, kulttuureiltaan, tavoitteiltaan ja myös arviointikäytännöiltään. Yhdessä kansanopistossa käytävä laatukeskustelu tuo esiin kuitenkin eri tulkintamahdollisuuksia ja syventää sekä laajentaa siten käsityksiä laadusta ja siihen liittyvistä haasteista. Otan seuraavassa esiin joitakin tutkimuksen tuottamia näkökohtia, joihin mielestäni olisi kiinnitettävä huomiota arvioitaessa laatuajattelun toteuttamista erityisesti kansanopistoissa.

\section{ENEMMÄN VÄHEMMÄLLÄ}

Laatu määrittyy tutkimuksessani organisaation suorituskyvyn parantamiseksi tai laatua otaksuttiin tarkasteltavan viimekädessä taloudellisen kehityksen valossa tai sitä sanottiin olevan pakko tarkastella opiston taloudellisen suorituskyvyn näkökulmasta. Ketjun, jossa tyytyväinen asiakas valitsee palvelun uudelleen, maksaa pyydetyn hinnan, keskittää hankintansa ja on uskollinen, tulkittiin osoittavan laadun talouden imperatiiviksi. Laatu ei pelkisty kannattavuutta kuvaaviksi numeroiksi, vaan pikemminkin taloudellisen suorituskyvyn parantamisen oikeuttamaksi välinepatteriksi.

Ymmärrettynä enemmän vähemmällä -periaatteeksi laatutyön nähtiin osin ratkaisevan niukenevien henkilöstöresurssien ja lisääntyvien vaatimusten synnyttämät ongelmat. Haastatteluissa käydään vuoropuhelua kahden strategisen vaihtoehdon välillä: toisaalta sanottiin olevan välttämätöntä etsiä kilpailuetua kustannuksien pienentämisestä eli operatiivista kilpailuetua, toisaalta oltiin hakemassa strategista kilpailuetua uusilla tuotteilla ja opiston uudella asemoinnilla markkinoille. Laatutyön merkitys nähtiin toiminnan vahvuuksien ja kehittämisalueiden paljastamisessa. Laadun parantamisen katsottiin edellyttävän jokaisen tehtävän ja toiminnan arviointia organisaation kaikilla tasoilla kannattavuuden ja markkinoiden näkökulmasta. Tuloksellisuuden todistamisen vaatimus ei siten jättänyt ketään ulkopuolelle.

Muutoksen vaatimus koettiin myös henkilökohtaiseksi haasteeksi: työtä kerrottiin siivittävän motivoiva pyrkimys yhä parempaan, mutta laatu samaistui myös toimintaperiaatteeseen " $k i$ ristetään ja kiristetään”, ”joustaa ja hyppää” ja "vaadittais tavallaan niin kuin vielä laadukkaampaa". Laatuajattelun koettiin silloin olevan omiaan synnyttämään kun mikään ei riitä -kult- tuuria Juha Siltalan (2004) käsitettä lainatakseni.

Taloudellisen suorituskyvyn nostamisen merkitystä perusteltiin valtion osuuden pienenemisellä, taustayhteisön vaatimuksilla, odotettavissa olevalla kysynnän kehityksellä ja kiinteistöjen kunnostustarpeilla. Tavoite selitettiin eräänlaiseksi pakoksi, se esiteltiin myös ikään kuin ymmärrettäväksi ja luonnolliseksi sekä toimintarationaliteetin muutokseksi: toiminnan arvo määrittyy rahamääräisenä kulutus- ja koulutusmarkkinoilla.

Taloushuolet ovat leimanneet kansanopistolaitoksen taivalta läpi vuosien, kuten Karttusen (1979) Suomen kansanopistojen historiikista voimme lukea, joten siinä ei sinänsä ole mitään uutta. Kun enemmän - ja enemmän vähemmällä - sekä vastiketta rahalle -periaatteet oli tiedostettu toimintaa ohjaaviksi normeiksi, voidaan olettaa niiden toteuttamisen merkitsevän osallistumista kilpailuun parhaiten maksavista asiakkaista ja näiden preferenssien ohjaamaa asiakaslähtöistä toimintaa. Voidaankin kysyä, saammeko sanoa hyvästit kansanopistojen kansalaisyhteiskunnan moninaisuutta ylläpitämälle ja generoimalle tehtävälle.

\section{"AJAN HERMOLLA"}

Kansanopistoväki perusteli laatuajattelua siihen liitetyillä jatkuvan muutoksen, parantamisen ja korjaamisen ideoilla. Käsityksissä kehittämisen, oppimisen ja muutosvalmiuden välttämättömyydestä tiivistyvät ammatillinen kunnianhimo sekä ajatukset elämästä jatkuvana muutoksena ja kansanopistotyöstä uusia tehtäviä etsivänä sekä muutosmahdollisuuksia generoivana. Muutoksella tarkoitettiin uusien palvelujen ja tuotteiden kehittämistä sekä opetuksen ja toimintatapojen uudistamista. Ajankohtaisten ja uudenlaisten näkökulmien tarjoamisen sanottiin viimekädessä legitimoivan opiston olemassaolon ja "se olis sit sitä laatuu”. Muutosta jo sinänsä pidettiin arvokkaana ja keskeiseksi kysymykseksi nousi, 3 "miten sen voisi tehdä toisin". Laadun parantamisen ja siihen liittyvien vaatimusten oli koettu siirtävän katseet myös entistä enemmän asian esittämiseen.

Vaikka haastatteluissa yksimielisesti sitouduttiin kehittämisen eetokseen, muodollinen laatuajattelu herätti myös epäilyjä. Olivatko laatuun liitetyt muutosvaatimukset johtamassa näennäiskehittämiseen, kritiikittömyyteen ja muutosten demonstrointiin sekä hämmästeltiin, "kuinka am- 
mattitaito voidaan mapittaa”? Ydinkysymyksiksi muodostuivat, luoko laatuajattelu edellytyksiä uuden kehittämiselle ja tuoko se mitään uutta kehittämistyöhön. Kaventaako se toiminnan mahdollisuudet kontroloiduiksi "laatumapeiksi”, normeiksi, standardeiksi ja virheiden metsästykseksi sekä näköalattomuudeksi? Ammatillisen tilan kapeneminen ja työn liukuminen tekijänsä ulottumattomiin nähtiin uhkana.

Toisaalta voidaan myös kysyä, eikö laatuajattelu uutena näkökulmana voi hyvinkin tehdä näkyväksi uusia asioita, tuoda uusia tulkintamahdollisuuksia ja synnyttää siten keskustelua ja näköaloja, jotka muuten jäisivät pimentoon.

\section{AVAUTUMINEN LAADUN ULOTTUVUUTENA}

Organisaation avautumisen, uusien yhteistyösuhteiden, sidosryhmien herkän kuuntelemisen ja keskinäisen yhteistoiminnan tiivistämisen, uskottiin luovan uusia toimintamahdollisuuksia. Markkinat nähtiin ehtymättömänä uusiutumisen lähteenä. Avautuminen on myös lupaus lisätä sidosryhmien vaikutusmahdollisuuksia opiston toimintaan. Ulkopuolisten kumppaneiden kanssa yhdessä toteutettujen hankkeiden kerrottiin rikastuttaneen myös talon sisäistä kommunikaatiota ja yhteistyösuhteita.

Talon käyttäjät tulkittiin asiakkaiksi ${ }^{2}$ ja asiakaslähtöisyys nähtiin toiminnan perustaksi; työ sai mielekkyytensä asiakkaan palvelemisesta ja tyytyväisestä asiakkaasta. Asiakaslähtöisyys tuotantokeskeisyyden ja asiantuntijavallan vastakohtana määrittyi toimintaorientaatioksi "kuunnella tarkalla korvalla” sidosryhmien tarpeita, mielipiteitä ja toiveita. Se ymmärrettiin asiakkaan palvelemisen ohella myös käsitykseksi, että asiakkuuteen liittyy oikeus esittää vaatimuksia, mihin katsottiin sisältyvän toiminnan dynamisuuden siemen.

Asiakassuhteeseen sisältyy implisiittisesti ajatus myös osapuolten intressien erilaisuudesta eli osapuolinäkökulmasta. Kun asiakassuhde tuodaan yhteistyösuhteisiin, voidaan kysyä, kaventaako asiakkuutta korostava toimintaorientaatio avoimen yhteistyön ja -toiminnan mahdollisuuksia. Opetushenkilöstö puhuikin mieluummin opiskelijalähtöisyydestä: opiskelijoista aktiivisina toimijoina, itseohjautuvuuden tukemisesta ja opiskelijoiden tarpeista opetuksen lähtökohtana. Opiskelijalähtöisyys opettamisen perustana tuntui luontevammin istuvan vuorovaikutusta, pedagogista suhdetta ja dialogia ${ }^{3}$ korostavaan käsitykseen oppimisesta ja opettamisesta. Jos koulutus sen sijaan ymmärretään tulkintojen, kommenttien ja kokemusten myynniksi, se redusoi opettajat myyntimiehiksi ja on omiaan tukemaan opiskelijoiden kuluttajaorientaation kehittymistä yleisemminkin sekä asioiden yksilöllistymistä: ylityöllistynyt ostaa särkylääkkeitä ja piristeitä, liikenteen melulta suojaudutaan lisäämällä ikkunakerroksia jne. (Bauman 1999; Marshall 1999).

Jo muutoksen ideaan sisältyy implisiittisenä ajatus myös arvioinnista. Itse-, vertais- ja asiakaskontrollin otaksuttiin luovan perustan organisaation avoimuudelle ja läpinäkyvyydelle sekä luottamussuhteiden rakentamiselle. Arviointi kietoo työntekijän normeihin ja standardeihin, kategorisoi, hierarkisoi, tekee näkyväksi ja johdettavaksi ja siis objektivoi työntekijän. Arviointia ei kuitenkaan haluttu nähdä niinkään kontrollin lisääntymisenä, vaan se haluttiin pikemmin liittää toiminnan kehittämiseen ja tulosten todentamiseen, vaikka tiedon arvioinnista jo sinänsä arveltiin ohjaavan toimintaa.

Opettamiseen ja myös muihin tehtäviin sinänsä katsottiin kuuluvan oman työn reflektointi, "semmonen kehitysnäkökulma". Arvioinnin ei uskottu koskaan voivan kokonaan vangita ammattitaitoon liittyvää osaamista, koska "siin on aina kaikkien persoonaa, siin on sitä hiljaista tietoa”. Sen katsottiin kuitenkin paljastavan virheitä ja luovan perustaa reflektiolle ja siten se tulkittiin liikkeelle panevaksi voimaksi. Itseasiassa itsearviointi eräänlaisena itsensä hajottamisena pitää jo sisällään lupauksen muutoksesta ja itsensä uudelleen rakentamisesta (Senge 1990). Arvioinnin uskottiin toisaalta sinänsä paljastavan tosiasioita ja tuottavan toiminnalle eräänlaisen "objektiivisen” ohjenuoran ja ratkaisuja, toisaalta sen hermeneuttista ja dialogista luonnetta korostettiin ja arviointien uskottiin avaavan uusia näköaloja osapuolille ja mahdollisuuksia vuorovaikutteisesti kehittyvän asiantuntemuksen kehittymiselle (ks. myös Schwandt 1997).

Jouhevan tiedonkulun ja sujuvan palveluketjun rakentamisen vaatimus oli siirtänyt katseet entistä enemmän myös keskinäisiin suhteisiin. Opistotyön arkisissa kohtaamisissa ja viestinnässä ei rakennettu vain laadukkaita palvelukokonaisuuksia vaan myös keskinäistä luottamusta, joka nähtiin toiminnan resurssina. Yhdessä tekemisen ja yhdessä arvioimisen kerrottiin synnyt- 
täneen "hedelmällistä” keskustelua ja voivan myös tukea yksittäistä työntekijää. Toisaalta lisääntyneen kiireen oli koettu kaventaneen mahdollisuuksia asioiden yhteiseen pohtimiseen ja keskinäisten suhteiden vaalimiseen. Laatuajattelu pakotti etsimään uutta tasapainoa autonomisuuden ja yhteisöllisyyden välillä: toisaalta laatuajattelu oli vahvistamassa yksilöllisen suoriutumisen ja pärjäämisen eetosta, toisaalta se oli houkuttelemassa yhteiseen projektiin.

\section{LUOTTAMUS TOIMINNAN PERUSTAKSI JA TAVOITTEEKSI}

$\mathrm{T}$ lutkimuksen laatukäsitys voidaan ymmärtää myös lupaukseksi organisaation kehittämispotentiaalista, yhä tehokkaammasta toiminnasta sekä lupaukseksi sidosryhmille ja asiakkaille mahdollisuudesta päästä vaikuttamaan yhä enemmän opiston toimintaan. Laatukäsitys voidaan tulkita osaksi luottamuksen rakentamista eri osapuolten välille, eräänlaiseksi neuvottelutarjoukseksi sidosryhmille yhteisten odotusten rakentamiseksi ja tulkinnaksi sidosryhmien toiminnalle asettamista odotuksista.

Luottamus voidaan ymmärtää joksikin, jota ihmiset rakentavat yhdessä ennustettavuuden lisäämiseksi ja keinoksi aktiivisesti kohdata epävarmuus ja ristiriidat. Laatuajattelu ei osoittaudu vain toiminnan tehostamisen ja kehittämisen välineeksi vaan myös toiminnan uskottavuuden rakentamisen perustaksi. (Ks. Grey \& Garsten 2001; Sztompka 1999.) Tutkimukset laadusta osoittavat kuitenkin, että muodollisen luottamusjärjestelmän rakentaminen saattaa synnyttää ja lisätä myös epäluottamusta. Offe (1999) huomauttaa, että luottamuksen rakentamisen välineet eivät läheskään aina ole luottamusta herättäviä ja jos ne havaitaan joidenkin intressien edistämisen välineiksi, ne eivät saa aikaan luottamusta vaan kyynisyyttä (ks. myös Buckley ja Hurley 2001; Sitkin ja Stickel 1996; Walgenbach 2001).

Luottamus saa tutkimuksessani kaksi ulottuvuutta: toisaalta se tulee esiin keskinäisten suhteiden ja toiminnan ohjauksen järjestämisen periaatteena toisaalta toiminnan uskottavuuden rakentamisena. Sidosryhmien luottamusta toimintaan otaksuttiin rakennettavan laatuteknologian (esim. asiakastyytyväisyysmittauksen) avulla, samalla kun kommunikaatiota haluttiin vahvistaa osapuolten yhteisten odotusten rakentamiseksi. Luottamusta opetukseen rakennettiin viimekädes- sä luokissa ja luottamuksen talon kykyyn hoitaa asioita uskottiin syntyvän henkilökohtaisissa kohtaamisissa. Kansanopistotoiminnan uskottavuuden otaksuttiin perustuvan osaavaan ja pätevään, luottamusta herättävään eli asiakkaiden kanssa vuorovaikutukseen ja dialogiin kykenevään henkilöstöön.

Laadun ulottuvuudeksi ja resurssiksi nähtiin myös työntekijöiden hyvinvointi, jonka kovaksi ytimeksi tutkimuksessa muodostuu eräänlainen vastavuoroisuuden eli luottamuksen periaate: me teemme parhaamme ja vielä enemmän, kun saamme siihen mahdollisuuden. Vastuuta jakavan ja työntekijöiden merkityksen osaavina ja arvostelukykyisinä tunnustavan johtamisen sekä keskinäisen arvostuksen ja tuen uskottiin luovan perustan laadukkaalle työlle ja toiminnan uskottavuudelle. Kommunikaatiossa ja dialogissa nähtiin oppimisen, hyvinvoinnin, vaikuttamisen ja osallisuuden mahdollisuus.

Toiminnan tehostumisen uskottiin lepäävän toisaalta laatuajatteluun liitettyjen objektiivisrationaalisen ohjauksen vahvistumisessa toisaalta hermeneuttisdialogisen mahdollisuuden avautumisessa, ts. sidosryhmien luottamusta toimintaan rakennettiin, toisaalta laatuajatteluun liittyvään teknologiaan, toisaalta sosiaalisessa vuorovaikutuksessa yhteisten odotusten rakentamiseen perustuen. Laatu ja luottamus liittyvät tutkimuksessani toisiinsa kaksoissidoksella: vuoropuhelua käytiin laadun ja luottamuksen objektiivisrationaalisen ja hermeneuttisdialogisen ulottuvuuden välillä. Tutkimus herättää kysymään, voidaanko ylipäätään toiminnan laatua kehittää kahteen hyvin erilaiseen taustaoletukseen perustuen järkyttämättä keskinäistä luottamusta.

Kokemus laatuajattelusta ulkoa tuotuna asiantuntijateknologiana synnyttää vieraantuneisuutta ja epäluottamusta, mutta kokemus vastavuoroisuudesta ja osallisuudesta luo edellytyksiä uusille merkityksille ja avauksille. Eriksen (2001) sanoo, että organisaation päätösten legitimiteetti ei lepää pelkästään niiden rationaliteetissa vaan myös niiden syntytavassa. Parhaat ratkaisut syntyvät perustellen dialogissa ja debatissa. Uusia haasteita taustaoletuksineen on tarkasteltava myös organisaation arvoja vasten, ennenkuin niiden merkitys avautuu ja ennenkuin niihin voidaan sitoutua (ks. myös Kekäle 1998). Organisaation kuten kansanopiston, joka toimii sidoksissa erilaisiin funktionaalisiin systeemeihin, on tasapainoteltava erilaisten vaatimusten ja 
erilaisten kulttuurien välillä, mikä edellyttää jatkuvaa toiminnan tulkintaa. Laatukysymyksiä ei voida käsitellä irrallaan toiminnan tehtävistä, tavoitteista ja periaatteista, ja siten myös ne vaativat jatkuvaa uudelleen määrittelyä.

Laatuajattelu oli tutkimukseni mukaan vahvistanut toiminnan asiakas- ja opiskelijalähtöisyyttä, tietoisuutta toiminnan tehokkuuden ja taloudellisuuden vaatimuksista sekä lisännyt edelleen yhteistyöhakuisuutta. Se nostaa esiin myös toiminnan ideaan ja perusteisiin liittyviä kysymyksiä ja aktualisoi keskustelun perinteen ja uusien vaatimusten yhteensovittamisesta, luottamuksesta ja kontrollista sekä työn yksilöllistymisestä ja yhteisöllisyydestä.

Missä on siis kansanopistotyön laadun ydin? Se on luottamuksen rakentamisessa eri asianosaisten välille. Se haastaa kansanopiston ja sen työntekijät yhä kiinteämpään vuorovaikutukseen ja dialogiin kansanopistotyöstä ja sen laadusta niin talon sisällä kuin sidosryhmien ja toimintaympäristön kanssa.

Useat tutkimukset (ks. esim. Baer \& Frese 2003) osoittavat luottamuksen organisaation voimavaraksi, joka luo edellytyksiä joustavalle toiminnalle ja uudistamiselle. Luottamusta voidaan pitää organisaation resurssina tai eräänlaisena turvaverkkona kuten Iivonen ja Harisalo (1997) asian ilmaisevat. Kun kansanopiston vahvuus eri väestöryhmiä palvelevana instituutiona on ollut muuntumiskyvyssä ja monitavoitteisuudessa, tulisi myös laatutyön ja laatukäsitteen merkityssisältöjen olla jatkuvan arvioinnin ja keskustelun kohteena.

\section{LÄHTEET}

Bauman, Z. (1999) Sosiologinen ajattelu. 2. painos. Vastapaino.

Baer, M. \& Frese, M. (2003) Innovation is not enough: climates for initiative and psychological safety, process innovations, and firm performance. Journal of Organizational Behavior 24, 45-68.

Buckley, F. \& Hurley, J. (2001) Change in the nature of the university: the quality regime and its effects on the university teaching environment. Social Science Information 40 (4), 545-576.

Eriksen, E. O. (2001) Leadership in a Communicative Perspective. Acta Sociologica 44, 2135.
Grey, C. \& Garsten, C. (2001) Trust, Control and Post-bureaucracy. Organization Studies 22 (2), 229-250.

Iivonen, M. \& Harisalo, R. (1997) Luottamus työyhteisön turvaverkkona yleisissä kirjastoissa. Finnish Information Studies 8. Tampere - Åbo - Oulu.

Juran, J. M. (1992) Juran on Quality by Design. The New Steps for Planning Quality into Goods and Services. New York: The Free Press.

Karttunen, M. O. (1979) Suomen kansanopisto 1889-1979. Suomen Kansanopistoyhdistys.

Kekäle, T. (1998) The Effects of Organizational Culture on Successes and Failures in Implementation of Some Total Quality Management Approaches. Towards a Theory of Selecting a Culturally Matching Quality Approach. Acta Wasaensia. No. 65. Industrial Management 1. Universitas Wasaensis.

Lecklin, O. (2002) Laatu yrityksen menestystekijänä. 4. painos. Gummerus.

Lillrank, P. (1999) Laatuajattelu. Laadun filosofia, tekniikka ja johtaminen tietoyhteiskunnassa. Otava.

Marshall, J. D. (1999) The Mode of Information and Education: Insights on Critical Theory from Michel Foucault. Teoksessa Popkewitz, T. S. \& Fendler, L. (eds.). Changing Terrains of Knowledge and Politics. Critical Theories in Education. New York and London: Routledge, 145-168.

Norman, H. \& Stapleton, J. (1992) The marketing dictionary. Butterworth-Heinemann.

Offe, C. (1999) How can we trust our fellow citizens? Teoksessa Warren, M. E. (ed.). Democracy \& Trust. Cambridge University Press, 42-87.

Schwandt, T. A. (1997) Evaluation as Practical Hermeneutics. Evaluation 3(1), 69-83.

Senge, P. M. (1990) The Fifth Discipline. The Art and Practice of the Learning Organization. London: Century Business.

Siltala, J. (2004) Työelämän huonontumisen lyhyt historia. Muutokset hyvinvointivaltioiden ajasta globaaliin hyperkilpailuun. Otava.

Simola, H. (2001) Koulupolitiikka ja erinomaisuuden eetos. Kasvatus 3/2001, 290 - 297. 
Sitkin, S. B. \& Stickel, D. (1996) The Road to Hell. The Dynamics of Distrust in an Era of Quality. Teoksessa Kramer, R. M. \& Tyler, T. R. (eds.) Trust in Organizations. Frontiers of Theory and Research. Thousand Oaks: Sage, 196-215.

Storbacka, K. \& Lehtinen, J. R. (1999) Asiakkuuden ehdoilla vai asiakkuuden armoilla. 4. painos. WSOY.

Sztompka, P. (1999) Trust. A Sociological Theory. Cambridge University Press.

Varmola, T. (1996) Markkinasuuntautuneen koulutuksen aikakauteen? Acta Universitatis Tamperensis 524 .

Virtanen, A. (2002) Uudella koulutuksella uudelle vuosituhannelle. Suomen 1990-luvun koulutuspolitiikka. Tampereen yliopisto. Kasvatustieteen laitos.

Walgenbach, P. (2001) The Production of Distrust by Means of Producing Trust. Organization Studies 22 (4), 693-714.

\section{VIITTEET}

1. Tutkimuksen aineistona oli yhdeksän kansanopistoväen yksilö- ja kolme ryhmähaastattelua.

2. Asiakas on henkilö tai organisaatio, joka tekee ostopäätöksen ja joka ei välttämättä ole kuluttaja tai käyttäjä. Asiakas on kaupankäynnin sopimusosapuoli (Norman \& Stapleton 1992). Laatujoh- tamisajattelussa asiakassuhteen nähdään vallitsevan aina, kun asiakkaalla on kontakti organisaatioon. Laatukirjallisuudessa asiakaslähtöisellä laadulla tarkoitetaan laadun subjektiivista puolta: miten hyvin palvelu tyydyttää käyttäjän vaateet ja tarpeet. Asiakas määrittää siis laadun. (Juran 1992; Lecklin 2002; Lillrank 1999.)

Asiakassuuntautuneella, -lähtöisellä, -keskeisellä ja -ohjautuvalla organisaatiolla tarkoitetaan organisaatiota, jonka toiminnassa on otettu eri tavoin asiakkaan tarpeet mahdollisimman pitkälle huomioon (Storbacka \& Lehtinen 1999). Tutkimuksessani ja tässä käytän asiakaslähtöisyyden käsitettä.

3. Keskustelu ja dialogi ovat diskurssin kaksi eri muotoa. Dialogissa lopputulos rakennetaan osapuolten vastavuoroisen osallistumisen ja vaikuttamisen pohjalta, se merkitsee merkitysten vapaata virtaa, eri näkökohtien ja oletusten punnintaa ja se johtaa omien ajatusten arviointiin. Siten dialogissa tuotetaan merkityksiä, jotka muutoin eivät aukenisi yksilölle. Keskeneräisyys, kontekstisidonnaisuus ja jatkuva mahdollisuus näkökulmien tarkistamiselle tekee vuorovaikutussuhteesta dialogisen, kun taas keskustelus sa osapuolet suostuttelevat muita omien näkemyksiensä taakse. (Sengen 1990.)

Päivi Tuomola-Karp (2005). Laatu luottamuksen rakentamisena - laatukäsitys kansanopistossa. Väitöstutkimus. 